1.01

\title{
Filip Čuček*
}

\section{Ivan Dečko v deželnem zboru v svojem prvem mandatu (1890-96)**}

\section{IZVLEČEK}

Avtor v prispevku analizira deželnozborske nastope spodnještajerskega poslanca Ivana Dečka v njegovem prvem mandatu (1890-96). Leta 1885 se je Dečko iz Maribora preselil $v$ Celje, se zaposlil $v$ Sernečevi odvetniški pisarni in vidno pospešil slovenski $\gg$ prodor $\ll v$ mestu ob Savinji. S premišljeno taktiko je nastopil tudi na deželnozborski ravni, ko je leta 1890 postal poslanec štajerskega deželnega zbora v ljutomerski kmečki kuriji. S svojimi deželnozborskimi govori, peticijami in interpelacijami je (skupaj z ostalimi slovenskimi poslanci) povzročal nemir $v$ nemških (liberalnih) vrstah in jih prisilil $k$ nacionalni homogenizaciji. Premetena slovenska politika je tudi pod njegovim vplivom na začetku 90. let popolnoma osvojila podeželje, spodnještajersko nemštvo pa omejila na mesta in nekatere trge.

Ključne besede: Štajerska, Avstro-Ogrska, Maribor, Celje, politična zgodovina, Ivan Dečko

\section{ABSTRACT}

\section{IVAN DEČKO'S FIRST TERM OF OFFICE IN THE PROVINCIAL ASSEMBLY (1890-96)}

In the present contribution, the author analyses the Provincial Assembly appearances of the Lower Styrian deputy Ivan Dečko during his first term of office (1890-96). In 1885, Dečko moved from Maribor to Celje, found employment in Josip Sernec's law firm, and visibly encouraged the Slovenian "breakthrough" in the city by the river Savinja. He also applied his thoughtful tactics at the level of the Provincial Assembly when he became a member of the Styrian Provincial Assembly in the Ljutomer rural curia in 1890. With his

* Dr., višji znanstveni sodelavec, Inštitut za novejšo zgodovino, Privoz 11, SI-1000 Ljubljana; filipc@inz.si

** Raziskava je nastala v okviru raziskovalnega programa P6-0281 Idejnopolitični in kulturni pluralizem in monizem na Slovenskem v 20. stoletju, ki ga financira Javna agencija za raziskovalno dejavnost Republike Slovenije. 
speeches, petitions, and interpellations in the Provincial Assembly, he and other Slovenian deputies stirred up unrest in the German (liberal) ranks and forced them into national homogenisation. Also under Dečko's influence, the clever Slovenian politics at the beginning of the 1890s won over the rural areas completely while restricting the Lower Styrian Germans to the cities and certain towns.

Keywords: Styria, Austro-Hungary, Maribor, Celje, political history, Ivan Dečko

\section{Uvod}

V parlamentarnih (pluralno urejenih) državah se z volitvami na (praviloma) periodično določeno število let zamenja državnozborska poslanska »zasedba «. Mandatarstvo za sestavo vlade navadno prejme predsednik najmočnejše stranke, ki (s podobno mislečimi strankami) oblikuje koalicijo in vladno »ekipo «, odgovorno za upravljanje države. Na drugi strani so za nadzor nad delovanjem vlade »pristojne « ostale nevladne stranke, ki tvorijo opozicijo. Koalicijo in opozicijo sestavljajo poslanci, ki so jih na volitvah izvolili volivci in jim zaupali svoj glas. Poslanci, ki predstavljajo določeno volilno okrožje oziroma zastopajo interese določene skupine ljudi, so vidnejši predstavniki javnega življenja, ki - tako ali drugače - soustvarjajo družbo. Nekateri, ki sicer v svojem lokalnem okolju precej izstopajo, širše nimajo posebnega vpliva oziroma svojo vlogo vidijo zgolj v suhoparnem izpolnjevanju zaupane naloge. Drugi pa morda $s$ svojo karizmo pomembno prispevajo k razvoju svoje regije (ali države) in so toliko vplivni, da so njihove odločitve in presoje pogosto ključne. Ne nazadnje so to v precejšnji meri tisti (poslanci), ki prevzemajo vajeti strank in tudi vzvode oblasti v svoje roke.

Tudi v ustavni dobi $\gg$ stare « Avstrije so bili poslanci bistven dejavnik političnega življenja. »Avstrijski« del monarhije (od leta 1867 Cislajtanija) je (podobno kot v današnji Avstriji, ki je razdeljena na dežele) sestavljalo več dežel (vsaka s svojim deželnim zborom in vlado). Sprva so se poslanci »rekrutirali $<$ deželnozborskimi volitvami, posledično zastopali najvišje politične ustanove (poslanci deželnih zborov in preko njih dunajskega parlamenta) in imeli pomembno vlogo pri političnih odločitvah. Po uvedbi neposrednih državnozborskih volitev leta 1873 so bili tako deželnokot državnozborski poslanci voljeni posebej. Ene in druge volitve so bile načeloma vsakih šest let (a ne istočasno). Najvišji predstavniki avtonomnih deželnih oblasti (deželni glavarji) so (praviloma) prihajali iz najmočnejše stranke, toda sankcioniral jih je cesar. $\mathrm{V}$ dunajskem parlamentu je ministrskega predsednika (ki večinoma ni prihajal iz poslanskih vrst) glede na razmerje $\gg$ sil « imenoval cesar. Ne glede na velike pristojnosti cesarja so bili voljeni $\gg$ zastopniki ljudstva « $\mathrm{v}$ avstrijski parlamentarni dobi pomemben člen pri izvrševanju zakonodajne oblasti. Med poslanci so sicer obstajale precejšnje razlike; eni so igrali večjo, drugi spet manjšo »vlogo «, številni so bili člani raznih odborov/odsekov, mnogi tudi ne. Nekateri so bili nosilci nacionalnih gibanj, 
po uvedbi modernih strank bolj ali manj njihovi prvaki. Drugi so se na sejah le redko oglašali in na političnem parketu niso igrali večje vloge. A ne glede na to so vsi spadali med avstrijsko (politično) elito. ${ }^{1}$

Poklicno je bilo veliko avstrijskih (državno- in deželnozborskih) poslancev pravnikov. Tudi med slovenskimi poslanci so bili številni pravniki. $\mathrm{V}$ kranjskem deželnem zboru je bilo denimo od leta 1883, ko ga je slovenska stran dokončno osvojila, od šestnajstih deželnih odbornikov kar sedem pravnikov, od štirih deželnih glavarjev pa dva pravnika. ${ }^{2} \mathrm{~V}$ štajerskem deželnem zboru v Gradcu je v slabih 60 letih slovensko politiko zastopala dobra tretjina pravnikov. ${ }^{3}$

Tudi glavni $\gg$ akter « pričujočega članka, Ivan Dečko, je bil pravnik. Sicer ni bil državnozborski poslanec in dunajskega parlamenta povsem »od blizu « ni poznal, zato pa je zastopal sprva deželnozborske volivce ljutomerske (1890-96), nato pa celjske kmečke kurije (1896-1907). Na sploh je delovanje slovenskih poslancev v deželnem glavnem mestu ob Muri relativno slabo obdelano. V nasprotju z dunajskim parlamentom, ki je bil doslej deležen večje pozornosti, ${ }^{4}$ je aktivnost spodnještajerskih politikov (kaj so $\mathrm{v}$ deželnem zboru govorili, katere teme so načenjali in $\mathrm{v}$ katere debate so se vključevali) v nekoč skupni štajerski prestolnici precej nepoznana.

Če je na Kranjskem slovenska stran zmagovala tudi v mestni kuriji in že leta 1867 osvojila deželni zbor, je bila na Spodnjem Štajerskem »slovenska « zgolj kmečka kurija. Slovenska politika je bila v Gradcu v zelo neugodnem položaju. Deželno politiko so namreč narekovali nemški ustavoverci, slovenski poslanci pa so dosegli le malo ali nič (kljub temu da je bil Fran Radej od leta 1887 namestnik deželnega glavarja ali pa Fran Robič od leta 1897 član deželnega odbora). Na drugi strani so se od osemdesetih let 19. stoletja naprej nacionalni odnosi precej zaostrili. Slovenska stran je v obdobju Taaffejeve vlade (tudi na Spodnjem Štajerskem) pridobila to ali ono koncesijo. V teh letih so izstopali predvsem »slogaši « Josip Sernec, Ivan Dečko, Lavoslav Gregorec, Miha Vošnjak idr. Vse od druge polovice devetdesetih let pa se je sloga počasi krhala. Če se je v Celju od preloma stoletja vse bolj krepila liberalna »meščanska « struja (Vekoslav Kukovec), so se pod vplivom politične diferenciacije na Kranjskem v Mariboru uveljavljali katoliški politiki mlajše generacije z Antonom Korošcem na čelu in svojo aktivnost (večinoma slovenski duhovščini) usmerjali na podeželje. Dokončen razdor so prinesle nadomestne državnozborske volitve leta 1906. Januarja 1907 sta bili tako oblikovani stranki obeh blokov (»celjska « Narodna stranka in »mariborska « Slovenska kmečka zveza). ${ }^{5}$

1 Gl. npr. Gernot Stimmer, Eliten in Österreich 1848-1970 (Wien, Köln, Graz: Böhlau Verlag, 1997).

2 Filip Čuček, »Izvršilna oblast na Slovenskem v zadnjih desetletjih dvojne monarhije (s poudarkom na kranjskih akterjih - še posebej pravnikih), « Prispevki za novejšo zgodovino 59, št. 2 (2019): 34.

3 Prim. Filip Čuček, »Slovenski poslanci v štajerskem deželnem zboru 1848-1878,« Časopis za zgodovino in narodopisje 90, št. 2 (2019): 14. Filip Čuček, »Spodnještajerski deželnozborski slovenski poslanci za časa Taaffejeve vlade, « Časopis za zgodovino in narodopisje 90, št. 3/4 (2019): 19. Filip Čuček, »Slovenski poslanci v Gradcu med prelomom stoletja in razpadom dvojne monarhije,« Časopis za zgodovino in narodopisje 91, št. 1 (2020): 35.

4 Več gl. Janez Cvirn, Dunajski državni zbor in Slovenci (1848-1918) (Celje: Zgodovinsko društvo; Ljubljana: Znanstvena založba Filozofske fakultete, 2015).

5 Prim. Filip Čuček, Svoji k svojim (Ljubljana: Inštitut za novejšo zgodovino, 2016), 42-60, 70-97, 126-37. 
$\mathrm{V}$ tem, $\mathrm{z}$ nacionalno noto prežetem času je Ivan Dečko slabe tri mandate potoval $\mathrm{v}$ Gradec in $\gg$ branil « slovensko politiko v ustanovi, ki jo je vseskozi prežemal nemški ustavoverni duh. Dečko, vodilni politik na Spodnjem Štajerskem na prelomu 19. in 20. stoletja, je strokovni javnosti sicer že precej poznan; ${ }^{6}$ njegova življenjska pot in njegovo splošno politično delovanje sta že bolj ali manj obdelana, manj znana pa je njegova aktivnost (oziroma nastopi) v graškem deželnem zboru. Dečkovi govori doslej še niso bili deležni podrobnejše analize, vsekakor pa si zaslužijo ustrezno obravnavo, s čimer bo njegov politični profil predstavljen mnogo bolj celovito.

Ko se je Dečko jeseni 1883 po končanem študiju prava zaposlil v odvetniški pisarni Ivana Orosela v Mariboru, se je nemudoma priključil (mariborski) slovenski politiki in bil precej aktiven. Leta 1885 se je preselil v Celje, se zaposlil v odvetniški pisarni Josipa Serneca in vidno pospešil slovenski $\gg$ prodor $\ll v$ mestu ob Savinji (na Sernečevo pobudo se je začel načrtno ukvarjati s problematiko enakopravnosti slovenskega jezika in prevzel nekakšen $\gg$ šolski referat $\ll) .{ }^{7} \mathrm{~S}$ požrtvovalnim organizacijskim delom na političnem, gospodarskem in kulturnem področju se je konec osemdesetih let tudi tam uvrščal med vidnejše predstavnike javnega življenja. Med njegove največje uspehe (leta 1887) sta sodila sprejemanje zemljiškoknjižnih prošenj in njihovo vknjiževanje v slovenskem jeziku ter preprečitev izvajanja ukaza štajerskega deželnega šolskega sveta, da se mora šolski pouk v zadnjem razredu ljudskih šol (med katerimi tedaj ni bilo več nobene popolnoma slovenske) poučevati v nemščini. S premišljeno taktiko je leta 1890 vstopil tudi v štajerski deželni zbor, kjer se je hitro zavzel za večjo veljavo slovenščine v spodnještajerskem javnem življenju. Konec leta 1891 je v Celju odprl lastno odvetniško pisarno in, poleg rednega odvetniškega dela, spisal marsikatero pritožbo, ki so jo dotični organi (ministrstva, namestništvo) praviloma sprejemali v slovensko korist. Slovenci so (tudi pod njegovim vplivom) na začetku devetdesetih let popolnoma osvojili podeželje, spodnještajersko nemštvo, ki je bilo vse bolj prestrašeno in je začelo naglašati, da se na Spodnjem Štajerskem odvija popolna »slovenizacija «, pa omejili na mesta in nekatere trge. ${ }^{8}$

Slovenska politika, ki je sicer v začetku devetdesetih let (tudi) na Spodnjem Štajerskem beležila lepe uspehe, je bila v štajerskem deželnem zboru v izredno slabem položaju. Medtem ko je na državnozborski ravni (od osemdesetih let naprej) pridobila določene koncesije in bila relativno uspešna tudi na lokalni ravni (občine in okrajni zastopi), je graški deželni zbor vseskozi ostajal v rokah nemških liberalcev. Od 60 voljenih poslancev so Slovenci v Gradcu (do leta 1904) mogli računati z največ osmimi mandati v kmečki kuriji (ostale tri kurije je obvladovala nemška stran). Slovenski poslanci so se lahko (pogojno) opirali le na (zgornještajerske) nemške konservativce, ki so imeli nekaj manj kot dvakrat toliko poslancev kot Slovenci. A ta

6 Gl. npr. Vekoslav Spindler, Dr. Ivan Dečko in njegova doba (Maribor: Tisk Mariborske tiskarne d. d., 1938). Franjo Baš, Prispevki k zgodovini severovzhodne Slovenije. »Doba Ivana Dečka (Maribor: Založba Obzorja, 1989).

7 Janez Cvirn, »Josip Sernec, rodoljub z dežele (spremna študija), « v: Josip Sernec, Spomini (Celje: Osrednja knjižnica Celje, 2003), 125.

8 Več o tem gl. Filip Čuček, »Politična dejavnost Ivana Dečka do začetka devetdesetih let 19. stoletja, Prispevki za novejšo zgodovino 52, št. 1 (2012): 21-38. 
koalicija je bila zgolj navidezna, kakšnega večjega vpliva pa ni imela. Nemški liberalci so mirno peljali svojo politiko in se na ostale niso preveč ozirali. Tudi Taaffejeva politika »sporazuma in sprave «, ki je sicer ponujala drugačno »smer «, ni spremenila razmerij moči v deželnem zboru. Nasprotno. Ustanovitev nemških nacionalnih društev (Deutscher Schulverein leta 1880, še posebej pa Südmark leta 1889) je povzročila eskalacijo nacionalnih konfliktov tudi tam. Zato so slovenski poslanci svoje nestrinjanje pogosto demonstrirali z vlaganjem raznih interpelacij, večkrat pa na ignoriranje odgovorili z abstinenco (kar se je od preloma stoletja zgolj stopnjevalo). ${ }^{9}$

\section{Dečkov prvi mandat}

Poslanci so v deželnih zborih sicer obravnavali različne teme, ki so bile na dnevnem redu. Štajerski deželni zbor je v svoji sedmi periodi (1890-96), podobno kot v prejšnjih, na rednih sejah obravnaval številne tekoče zadeve. Poslanci so se v vseh sesijah ukvarjali z bolj ali manj splošnimi zadevami (železnica, deželne ceste, hranilnice, kmetijstvo, lovstvo, odkup kmečkih posesti, policijske zadeve, bolnišnice, ubožnice, šolstvo, občinske zadeve, vodogradnje, regulacije rek idr.), na drugi strani pa so v vsaki sesiji posebej obravnavali tudi specifične teme (denimo celjsko gimnazijsko vprašanje, ki je povsem zaznamovalo peto sesijo). ${ }^{10}$

Leta 1890, ko je Taaffejeva vlada že več kot desetletje »krmarila« avstrijsko »barko«, je bil torej Dečko kot poslanec ljutomerske kmečke kurije izvoljen v graški deželni zbor. Njegov prihod je nedvomno okrepil slovenska prizadevanja, toda zaradi nemške liberalne večine večjega premika ni bilo, kljub temu da je deželni glavar grof Wurmbrand $\gg v$ svojem nagovoru razkrival tudi nekak načrt za delovanje, ki čaka gg. dež. poslance $v$ tej dobi in če se poprime dež. zbor tega načrta in ostane le pri njem, tedaj se nam ni bati, da pride veliko dobrega za nas «, glede na to pa, da $\gg$ kolikor poznamo doslej nemške liberalce, ki sede $\mathrm{v}$ dež. zboru, ni jim za drugo veliko mar; če morejo v tem le kje kako do kake brce za slov. ljudstvo, brž so za to $\mathrm{k}$ redu $\ll .{ }^{11} \mathrm{~V}$ prvi sesiji, ki je trajala od 14. oktobra do 22. novembra 1890, se Dečko sicer ni veliko javljal k razpravi, ne glede na to pa so bili njegovi govori tehtni in premišljeni. ${ }^{12}$ Potem ko je 6. novembra na 11. seji vložil peticijo prebivalcev Krapja pri Ljutomeru, ki so se želeli odcepiti od občine Cven in ustanoviti svojo občino, se je na isti seji prvič oglasil. Skupaj z Josipom Sernecem je ostro nasprotoval nameri celjskega župana Josefa Neckermanna, ki si je (za zagotovitev javne varnosti v mestu ob Savinji) prizadeval

9 Prim. Čuček, Svoji k svojim, 94-99. O štajerskem deželnem zboru gl. več Edith Marko-Stöckl, »Der steiermärkische Landtag, « v: Die Habsburgermonarchie 1848-1918, Band VII/2 (Wien: Verlag der österreichischen Akademie der Wissenschaften, 2000), 1683-1718.

10 Sachregister zu den stenographischen Protokollen über die Verhandlungen des steierm. Landtages. VII. LandtagsPeriode. II. Session 1891/92, III. Session 1892/93, IV. Session 1893/94, V. Session 1894/95, VI. Session 1895/96.

11 Slovenski gospodar, 30.10.1890.

12 Seveda je treba opozoriti, da je bil Dečko kljub temu aktiven že od samega začetka. Slovenska politika je namreč delovala enotno; interpelacije in zahteve, ki so jih vlagali slovenski poslanci, je brez izjeme podpiralo vseh osem poslancev, v nekaterih zadevah pa so bili med podpisniki tudi katoliški konservativci. 
za zvišanje kazni, saj da »bode s časom še nevarno, ako rečeš komu: dobro jutro «, mestna uprava pa da »postavi lehko na tako pozdravljenje kazen 50 gld. in če se drzne ga človek kedaj izreči, plača jih brez usmiljenja, kakor se bere v načrtu nove postave, 'v mestno kaso' «. ${ }^{13}$ Župan (in deželnozborski poslanec) je namreč po ekscesnih dogodkih, ki so v začetku septembra zaznamovali Celje - ob hkratni manifestaciji Celjskega Sokola in celjske krajevne skupine Südmark je prišlo do nemirov, ki so kulminirali v vsesplošnem pretepu -, v deželnem zboru predlagal spremembo 26. in 47. člena občinskega statuta, s čimer bi tako drastično zvišal kazni. Sernec, sicer član deželnozborskega občinskega odseka, ki je predlog podprl in dal v razpravo, je svoje nestrinjanje z Neckermannovim početjem utemeljeval z dejstvom, da kazni vsebuje že kazenski zakonik in da ni nobene potrebe, da bi občina samovoljno zviševala kazni. S to potezo je občinski zastop (in posredno župan) želel še okrepiti svojo moč v mestu, s čimer bi v prihodnje uspešno preprečeval neželene (slovenske) dogodke. Prav tako je menil, da bi moral župan s pomočjo krajevne policije imeti popoln nadzor nad dogajanjem, česar pa mu septembra ni uspelo zagotoviti. Septembrski nemiri, ki so bili tako rekoč začetek ekscesnih dogodkov v Celju, so zgolj definirali stališče mestnih oblasti do slovenskih prireditev, ki so jih poskušali z raznimi odloki prepovedati ali vsaj omejiti. Prav tako niso bili slove(a)nski udeleženci dvodnevnih prireditev od krajevne policije deležni nikakršne zaščite (medtem ko so zaščito zagotavljali nemškim prenapetežem), to pa se je v naslednjih mesecih le še stopnjevalo. Vse to je Serneca navdajalo s strahom, da bodo ukrepi služili le za zastraševanje slove(a)nskega prebivalstva in da jih bo predvsem policija izrabljala v nemško korist. ${ }^{14}$

Neckermann, ki je Sernečev govor poslušal iz poslanskih klopi, je nemudoma odgovoril in trdil, da slovenski poslanec navaja kup neresnic, da je celjski občinski zastop (pod njegovim vodstvom) septembra ravnal pač v skladu z zakonom in skušal $\mathrm{v}$ prvi vrsti zagotoviti javni red in mir v mestu, saj je bilo sokolsko slavje zgolj nacionalno-politična manifestacija, ki je povzročila preplah med $\gg$ miroljubnim « mestnim prebivalstvom. Obenem je ponovno pozval, da naj odsek trezno razmisli in glasuje za njegov predlog. ${ }^{15}$ Temu je nasprotoval Ivan Dečko, ki je prvič nastopil v »visoki

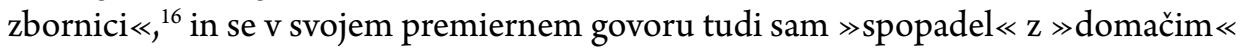
županom. Očital mu je, da izkorišča trenutni položaj za zagotovitev popolne oblasti v mestu, da bo z zvišanjem kazni zgolj utrdil svojo moč in da mu sploh ne gre za ugled mesta, ki je (vsaj v nacionalnem smislu) že tako ali tako močno načet. Ugled, tako Dečko, se pridobi s postopanjem in ravnanjem, nikakor pa ne z višanjem kazni (sploh če so naperjene proti točno določeni skupini ljudi), ki zgolj poglablja že tako napeto stanje. Po drugi strani pa je ugotavljal, da mest(ec)a kot Celje ne bi smela dobiti

13 Slovenskigospodar, 13. 11. 1890.

14 Stenographische Protokolle über die Sitzungen des steierm. Landtages. VII. Landtags-Periode. I. Session, 11. Sitzung, 6. 11. 1890, 79-81. Prim. tudi Filip Čuček, Uspehi spodnještajerskih Slovencev v Taaffejevi dobi (Celje: Zgodovinsko društvo, 2007), 235-47.

15 Stenographische Protokolle über die Sitzungen des Steierm. Landtages. VII. Landtags-Periode. I. Session, 11. Sitzung, 6. 11. $1890,81,82$.

$16 \gg$ Hohes Haus «. 
mestnega statuta, saj so premajhna in sploh ne premorejo pravega mestnega duha, ter da je zmeraj na oblasti klika, ki skrbi zgolj za svoj žep in zlorablja občinsko upravo v svojo korist. Dečko, ki si je privoščil pravi napad na celjskega župana, je bil od liberalne večine sicer deležen nemajhnega posmeha, dejansko pa je razgrnil pristransko postopanje celjske mestne občine, ki je s slovenskimi in nemškimi strankami (najemniki lokalov in drugih obratov) ravnala povsem drugače. Slovenski podjetniki naj bi dobivali številna polena pod noge, ko je šlo za razne gospodarske dejavnosti, medtem ko so nemški poslovali povsem nemoteno. Prav tako je dokazoval, da je krajevna policija delovala v prid nemškega prebivalstva, saj se slovenskih udeležencev septembrskih dogodkov - v pomoč ji je bilo tako orožništvo kot tudi vojaška četa - sploh ni trudila zaščititi oziroma preprečiti škandala, pač pa ga je še podpihovala. ${ }^{17}$

Njegovemu izvajanju je nasprotoval slovenjgraški poslanec Theodor Starkel, češ da gre zgolj za provokacije nemških »nasprotnikov«, in svojim zgornje- in srednještajerskim kolegom dokazoval »dejansko « spodnještajersko sliko: da je nasprotna, torej slovenska stran ( $\gg$ gegnerische Seite $\ll$ ) z vsemi sredstvi (in podprta s slovenskim tiskom) izvajala pritisk in netila nacionalni nemir, da zgolj ona povzroča nacionalni boj, ki prežema deželo, in da skušajo slovenski poslanci razdor vnesti tudi v deželni zbor. Dejal je, da so spodnještajerska mesta nemška in da želijo nemška tudi ostati, po drugi strani pa zatrjeval, da je društvo Südmark svojo prireditev najavilo mnogo pred Celjskim Sokolom, ki je glede tega kriv za nastali položaj v mestu. Kakorkoli, Neckermannov predlog je deželni zbor, potem ko je bila seja na pobudo poslanca Josefa Proboschta zaključena, potrdil. ${ }^{18}$ Slovenski poslanci glede na sestavo poslanske zbornice niso imeli nikakršne možnosti, da bi jim uspelo preprečiti njegovo sprejetje.

Nastop slovenskih poslancev seveda ni ostal neopažen. Spodnještajerski tisk je najbolj »napadel « vodjo celjskih Slovencev, Serneca, ${ }^{19}$ medtem ko je Dečku, ki se je $\mathrm{v}$ deželnem zboru povsem dobro znašel, še nekoliko »prizanesel «. Sicer je Dečko v Gradcu brez izjeme glasoval z ostalimi slovenskimi poslanci, ko so ti kot prvopodpisani vlagali interpelacije ali razne pobude, ostali pa so se prav tako pridruževali njegovim »akcijam «. Drugič se je Dečko oglasil na 16. seji 15. novembra 1890, ko je vložil interpelacijo v zvezi z ravnanjem oblasti glede nemirov v Rožnem dolu pri Mali Nedelji pred slabim mesecem dni. V nedeljo, 26. oktobra, se je namreč v kraju zbrala večja množica ljudi, saj naj bi se tam že več mesecev prikazovala Devica Marija. Okrajno glavarstvo je tja napotilo orožniško četo, ki bi morala zagotoviti red in disciplino (oziroma razgnati množico, saj je bilo večje zbiranje prepovedano). Čez dan je prišlo med nekaj fanti in orožniki do prerivanja, pri čemer je vodja čete ustrelil Antona Zemljiča in Ivana Domanjka in ju tudi ubil. Dečko in ostali slovenski (in nemški konservativni) poslanci so trdili, da orožniki niso postopali v skladu z zakonom, da prebivalstvo ni bilo seznanjeno s prepovedjo, sploh pa da bi moral biti navzoč tudi okrajni komisar, ki bi

17 Stenographische Protokolle über die Sitzungen des steierm. Landtages. VII. Landtags-Periode. I. Session, 11. Sitzung, 6. 11. $1890,82-85$.

18 Ibidem, 85, 86.

19 Prim. Deutsche Wacht, 9., 20. 11. 1890. 
umiril zadevo. ${ }^{20}$ Namestnik Kübeck je slab teden kasneje odgovoril in pojasnil, da se je tisto nedeljo res zbrala velika množica ljudi, določeni pobalini pa so izzivali orožnike, ko so hoteli ljudem pojasniti, da so tam protizakonito, in da je okrog sto fantov z noži napadlo orožniško četo, ki se je zgolj branila. ${ }^{21}$

Če je bila ta interpelacija ena zadnjih, ki na prvem mestu ni poudarjala napetih nacionalnih odnosov, pač pa naj bi dogodku botrovala $\gg$ nemirna kri vnetih mladeničev«, je Dečko štiri dni kasneje (19. novembra) prebral interpelacijo, v kateri je v slovenščini pozival namestnika, naj odpravi nepravilnosti na nekaterih spodnještajerskih okrajnih glavarstvih, ki so na slovenske prošnje odgovarjala v nemščini. »Deželni glavar je v seji dne 19. novembra naznanil zboru, da je dobil pismo, ki ga ne zna ni on, ni kateri zapisnikar brati. Pooblaščeni tolmač, prof. Hubad, še mu je le razodel, kaj da pomeni pismo - slov. interpelacija je poslanca dr. Dečko do c. kr. namestnika. Na to poslanec dr. Dečko prebere interpelacijo v slov. jeziku, poslanec Proboscht pa nje nemško prestavo. Dr. Dečko vpraša v njej ces. namestnika, ali mu je znano, da se od večih c. kr. okr. glavarstev ne odgovarja na slov. prošnje in sploh ne posluje slovenski in če ga je volja to razvado odpraviti. $\ll{ }^{22}$ Čez dva dni je namestnik diplomatsko odgovoril in zatrdil, da so okrajna glavarstva vsekakor primorana odgovarjati v jeziku, v katerem je vloga vložena, in da je na Spodnjem Štajerskem to tako ali tako redna praksa, ${ }^{23} \mathrm{kar}$ pa, vsaj glede na Dečkovo interpelacijo, ni povsem držalo. Ko je navajal, da veliko spodnještajerskih uradov ne spoštuje 19. člena decembrske ustave o enakopravnosti jezikov, pač pa da vračajo zgolj nemške odgovore, so iz ustavovernih klopi zadoneli klici $\gg$ Bravo! «, njegove besede, da v majhnih podeželskih občinah velikokrat nihče ne razume nemško, pa so pospremili s klici »Sehr traurig! « in $\gg$ Ja wohl! «, ko je menil, da se občinska predstojništva ne bodo učila nemščine zgolj zaradi nemških dopisov. Na koncu je bil deležen nemajhnega posmeha, ko je zaključil, da je vendar po »zdravi kmečki pameti $\ll$ jasno, kaj 19. člen dejansko predpisuje. ${ }^{24}$

$\mathrm{Na}$ isti seji se je Dečko oglasil še dvakrat. Prvič je (skupaj z Josipom Sernecem) deželnemu zboru (in odboru) pojasnjeval zadeve glede sistema jamstva Južnoštajerske hranilnice, ${ }^{25}$ drugič pa je (skupaj s poslancem Jožefom Lipoldom) protestiral proti ponemčevanju slovenskih ljudskih šol in se postavil $\gg$ zoper dež. odbor, ki gleda le na to, da se v šolah nemčuri, manj pa mu je mar za pravo napredovanje $\ll .{ }^{26}$ Deželni odbor je namreč menil, da je »'poduk v nemškem jeziku za štaj. Slovence toliko važen, da moramo tako prav pregreho imenovati, ki se stori štaj. Slovencem, ako se jim jemlje ali tudi le krati priložnost naučiti se nemškega jezika' «, medtem ko je deželni šolski svet očitno »pozabil «, da je »naučno « ministrstvo njegov sklep, da se v tretjem razredu

20 Stenographische Protokolle über die Sitzungen des steierm. Landtages. VII. Landtags-Periode. I. Session, 16. Sitzung, 15. 11. 1890, 129.

21 Ibid., 21. Sitzung, 21. 11. 1890, 261-63.

22 Slovenski gospodar, 27.11. 1890.

23 Stenographische Protokolle über die Sitzungen des steierm. Landtages. VII. Landtags-Periode. I. Session, 21. Sitzung, 21. 11. $1890,263$.

24 Ibid., 19. Sitzung, 19. 11. 1890, 183, 184.

25 Ibid.

26 Slovenski gospodar, 27.11. 1890. 
ljudskih šol poučuje v nemščini, že leta 1887 sistiralo. Septembra 1890 je namreč ponovno sklenil, da se v slovenščini poučuje zgolj v prvih dveh razredih ljudskih šol. ${ }^{27}$ Temu je Dečko ostro nasprotoval in dejal, da smo $\gg$ zoper to, da se vpelje nemščina $v$ slov. ljudske šole, iz uzrokov zdravega vzgojstva, / ... / vrhu tega pa še tudi zato, ker se kratko in malo nič ne more doseči, kar se s tem poukom namerava «, saj sam deželni odbor priznava, da »ovira veliko število učnih predmetov podučevanje $v$ nemškem jeziku in to celo tedaj, ako se odločijo posebne ure za obvezno podučevanje v nemščini. Tedaj pa se pač vsiljuje predmet $v$ ljudske šole, v kateri za-nj ni mesta. Podučevanje v tujem jeziku je za deco, ki ne zna tega jezika, prava muka in torej bi pač naj ne trpinčili $s$ tem dece brez potrebe «, poleg tega pa »smo razvideli, da se skrbi za poučevanje v nemškem jeziku na slov. ljudskih šolah samo le zato v toliki meri, da jim postane ljudska šola pripomoček za izdatno ponemčevanje «. V nadaljevanju je pokazal nekaj ukazov deželnega šolskega sveta o vpeljavi nemščine kot učnega jezika na nekaterih ljudskih šolah, kar je bilo seveda v nasprotju s sklepom »naučnega « ministrstva, ko $\mathrm{mu}$ je deželni glavar vzel besedo, češ da naj ukazov ne bere, saj bi moral to prej naznaniti, »da dež. zbor odloči, sme-li brati ali ne «. Dečko je deželnega glavarja zavrnil, češ da ukazov nikakor ne bere, pač pa zgolj našteva primere, ki kažejo na pronemško postopanje šolskega sveta. Ti primeri vznemirjajo »slov. ljudstvo prav močno, kajti uvidi se lehko, da gre za glavo slov. ljudski šoli, ako se dela po tem načinu naprej«. Zato se je seveda zavzel za slovensko ljudsko šolo in menil, da če $\gg$ bi se bili postavili na pametno stališče, pa bi dali nekaj ur poduku v nemškem jeziku, tedaj bi se ne bil noben Slovenec vzdignil zoper to «, sedaj pa $\gg$ smo razpoznali, da se ta stvar pretira ter nam odganja celo upanje do napredovanja, do narodnega življenja $\ll$, in $\gg$ sklenili, da nam jo bode odriniti, potisniti jo v $\operatorname{stran} \ll{ }^{28}{ }^{28}$

Kljub Dečkovemu obširnemu izvajanju to seveda ni prineslo večjega uspeha. Nasprotno. $\gg$ Vahtarca $\ll$ je takoj $v$ naslednji številki $\gg$ obračunala $\ll \mathrm{z}$ dvema slovenskima poslancema (»wendischen Abgeordneten «), ki ju sploh ni poimensko navedla. ${ }^{29}$ Glede upoštevanja slovenščine $\mathrm{v}$ javnem življenju so si spodnještajerski Slovenci lahko več obetali od državnega zbora in njegovih sklepov, medtem ko so bili v deželnem zboru v precej neugodnem položaju. Kljub temu je Dečko pri oceni prve sesije menil, da so v preteklem letu vseeno nekaj dosegli in prisilili nemške poslance, $\gg$ da se je spremenil upravilni red toliko, da zamore že 6 poslancev samostalne predloge staviti in da vsaj enega slovenskega poslanca morajo v vsak odsek voliti, dosegli so železnico po Savinjski dolini, ki se že stavi, potegovali so se za spremembo lovske postave, ki se mora spremeniti na korist sadjerejcem «, in da so se »krepko upirali ponemčevanju po šolah in uradih in glede na uradovanje so vsaj toliko dosegli, da uradi morajo na slovenske uloge slovenski odgovarjati $\ll^{30}$

27 Slovenski gospodar, 27. 8. 1891.

28 Stenographische Protokolle über die Sitzungen des steierm. Landtages. VII. Landtags-Periode. I. Session, 19. Sitzung, 19. 11. 1890, 216-19. Slovenski gospodar, 18., 25. 12. 1890.

29 Deutsche Wacht, 23. 11. 1890.

30 Slovenskigospodar, 21.5. 1891. 
Ne glede na to so se nacionalna nasprotja vse bolj zaostrovala. Posebej v Celju so nacionalni ekscesi že postali del vsakdana, zato nikakor ne preseneča Sernečeva izjava iz marca 1891, ko je na obravnavi pred celjskim sodiščem izjavil, da je Celje, kar se nacionalnih odnosov tiče, najbolj razvpito mesto v monarhiji. To se je pokazalo že konec avgusta ob cesarjevem obisku mesta, ko so celjski Nemci (z izključitvijo Slovencev) visoke goste skušali prepričati, da je Celje povsem nemško mesto. ${ }^{31} \mathrm{Na}$ drugi strani so slovenski uspehi v mestu in okolici nemško stran (spodnještajersko, in ne zgolj celjsko) vse bolj silili $\mathrm{k} \gg$ obrambi «, tako da sta obe strani začeli svojo nacionalno politiko vse bolj homogenizirati. ${ }^{32} \mathrm{~V}$ teh razmerah se je konec leta 1891 začela naslednja sesija deželnega zbora (dve seji sta bili 28. in 29. decembra 1891, nato pa spet od 3. marca do 8. aprila 1892). Tri dni pred silvestrovim so se štajerski poslanci zbrali na prvi seji, domov pa so odšli že naslednji dan, ko so sesijo do 3. marca prekinili. $\mathrm{V}$ drugi sesiji se Dečko decembra ni priglasil, zato pa se je prvič oglasil 31. marca, ko je bila na 21. seji na mizi debata o železniški progi Celje-Šoštanj-Velenje in je med slovenskimi poslanci povzročila nemalo razburjenja. Deželni odbor, v katerem je imel »hammer-amboss « (mariborski poslanec Josef Schmiderer) glavno besedo, je sklenil ob progi postaviti zgolj nemške napise, medtem ko so bila v slovenščini predvidena le opozorila. Na proteste slovenskih poslancev, češ da se deželni odbor $\gg$ ni spomnil enakopravnosti slov. jezika ter je dal napise pri postajah narediti le v nemškem jeziku «, je Schmiderer odgovoril, da so nemške napise »želela mesta pa tudi več slov. občin«, da je to $\gg v$ listinah« in da bi dvojezični napisi samo motili. Njegovemu izvajanju so slovenski poslanci družno ugovarjali, nato pa je Dečko (po Lipoldovem govoru) odgovoril, da »kjer teče sedaj železnica, tam so Slovenci in njih ne kaže žaliti; nemški jezik se zato ne prezira, če so napisi nemški in slovenski skupaj. Svarila so v obeh jezicih, čemu bi ne bile tedaj tudi postaje v obeh? « Potem ko je poudaril, da na Spodnjem Štajerskem živijo tudi Slovenci, se mu je zdelo logično, da so napisi v obeh jezikih, še sploh po tem, ko je Južna železnica že pred nekaj leti sklenila postaviti dvojezične table južno od Šentilja (kljub temu da so nekatere nemške občine temu nasprotovale in znotraj svojih meja dosegle postavitev zgolj nemških napisov). Glede na to, da je bila nova železniška proga v nasprotju z Južno železnico zgrajena na deželne stroške, ni bilo nič čudnega, da so označevalni napisi naleteli na takšen odpor. Povedal je tudi, da so Slovenci na državni ravni že priznani kot narod, ki ima tudi svoje pravice, medtem ko je bilo na Štajerskem povsem drugače. Tam je deželni odbor imel vso moč, slovenščino in Slovence pa so enostavno ignorirali, kjerkoli se je le dalo (slovenščina ni bila predvidena niti v voznih redih). ${ }^{33}$

$\mathrm{Na}$ Dečkov govor se je odzval poslanec Rudolf baron Hackelberg in zgodbo obrnil, češ da »na Spodnjem Štajerskem živijo tudi Nemci «, Slovenci pa jim »nočejo priznati enakopravnosti, kajti v večih občinah ne najde človek nemških napisov«. Ko je dejal,

31 Bojan Cvelfar in Andrej Studen, »Posameznosti iz vsakdanjega življenja v Celju pred prvo svetovno vojno, « v: Iz zgodovine Celja 1848-1918. Odsevi preteklosti 2 (Celje: Muzej novejše zgodovine, 1998), 342-47.

32 Cvirn, Josip Sernec, 131-33. Čuček, Svoji k svojim, 98-103.

33 Stenographische Protokolle über die Sitzungen des steierm. Landtages. VII. Landtags-Periode. II. Session, 21. Sitzung, 31. 3. 1892, 189-94. 
da se »torej Slovenci postavljajo tako na zadnje noge «, je izzval »velik krik na strani slov. in kons. poslancev«, za kar se je sicer opravičil, da mu je »beseda le ušla (?) ter da ni hotel žaliti slov. poslancev «, nato pa nadaljeval, da »če slov. ljudstvo tirja slov. napise na železniških postajah, naj pustijo tudi nemške napise v občinah «. Hackelbergu je oporekal še Miha Vošnjak, upokojeni železniški inženir, ki se je vsekakor strinjal s svojima slovenskima kolegoma in navajal, da na Spodnjem Štajerskem živi 90 odstotkov Slovencev in 10 odstotkov Nemcev. Na drugi strani pa sta baronu »prišla na pomoč dr. Starkel in dr. Kokošinek, oba pa tako, da bi bila storila bolje, ko bi bila déla jezik za zobe $\ll .{ }^{34}$ Prvi je menil, da nikakor ne drži, da so okrog proge zgolj slovenski kraji (in hitro našel Šoštanj in Velenje, ki sta bila večinsko nemška), medtem ko je drugi protestiral, češ da pri gospodarskih zadevah ni prostora za nacionalno problematiko. ${ }^{35}$

Po burni debati se je Dečko drugič (in zadnjič v tej sesiji) javil k besedi 2. aprila, ko je spet načel perečo problematiko uvajanja nemščine kot učnega jezika v (slovenske) ljudske šole. V interpelaciji, ki jo je ponovno prebral v slovenščini, je poudaril šolo v Makolah na Dravskem polju, kjer so v ljudsko trirazrednico po vsej sili hoteli vpeljati nemščino že v prvem razredu, kljub temu da so vse občine, ki so otroke šolale na dotični šoli, poslale na deželni šolski svet prošnjo, da se nemščina uvede kot učni predmet, ne pa kot učni jezik. Predvsem ga je zmotilo dejstvo, da je odgovor deželnega šolskega sveta »obstal « na okrajnem šolskem svetu Slovenska Bistrica, da se zadeva že skoraj štiri leta ni premaknila, posledično pa seveda ni bila rešena. Ponovno je poudaril, da nemščina nikakor ni primerna kot učni jezik in da bi morala biti v slovenskih ljudskih šolah slovenščina brez izjeme učni jezik, nikakor pa ne zgolj učni predmet, kar je postala ponekod že kar praksa. ${ }^{36} \gg$ Marburgerca $\ll$ je Dečka (in ostale slovenske poslance), ki so se zgolj zavzeli za spoštovanje že doseženega (sklep »naučnega $\ll$ ministrstva), ostro napadla in označila za nasprotnike nemštva (»die Gegner des Deutschtums $\ll) .{ }^{37}$

Naslednja (tretja) sesija se je začela po poletnem premoru sredi septembra (med 9. in 17. septembrom 1892), nadaljevala in končala pa se je spomladi 1893 (od 6. aprila do 3. maja 1893). Potem ko je bil skupaj z nekaj nemškimi poslanci (Moore, Mayr, Moscon, Kotzbeck, Proboscht) Dečko med podpisniki interpelacije (24. april) glede nerednih izplačil delavcem pri regulaciji Mure pri Lipnici in Cmureku, ki so jo prebrali na 20. seji 26. aprila, ${ }^{38}$ se je v tej sesiji oglasil zgolj enkrat, na naslednji seji 27. aprila, ko je ostro nasprotoval poslancema Kokoschineggu in Starklu pri njuni agitaciji, da se trga Ljutomer in Šoštanj izločita iz šolskih občin in dobita nemško šolo, češ da sta to trga, kjer je večinsko prebivalstvo nemško. ${ }^{39}$ Njunima resolucijama je Dečko ugovarjal in

34 Slovenskigospodar, 7. 4. 1892.

35 Stenographische Protokolle über die Sitzungen des steierm. Landtages. VII. Landtags-Periode. II. Session, 21. Sitzung, 31. 3. 1892, 194, 195.

36 Ibid., 23. Sitzung, 2. 4. 1892, 236, 237, 254-56.

37 Marburger Zeitung, 3., 7. 4. 1892.

38 Stenographische Protokolle über die Sitzungen des steierm. Landtages. VII. Landtags-Periode. III. Session, 20. Sitzung, 26. 4. 1893, 197. Slovenski gospodar, 4. 5. 1893.

39 Stenographische Protokolle über die Sitzungen des steierm. Landtages. VII. Landtags-Periode. III. Session, 21. Sitzung, 27. 4. $1893,260$. 
poročal o vse večjem številu slovenskih pritožb zaradi neupoštevanja (sicer zakonsko zajamčene) nacionalne enakopravnosti. Ljudske šole so bile po njegovem ustanove za ponemčevanje slovenskih otrok oziroma jih je nemška stran enostavno zlorabila za ponemčevanje, spet pa je ponovil, da je bila marsikje že v prvem razredu nemščina učni jezik, ne pa zgolj učni predmet. Menil je, da je bilo šolstvo v tistih trgih, kjer je prebivalo tudi nemško prebivalstvo, veliko bolj »na udaru «, saj je bila tam nemudoma ustanovljena nemška šola, ne glede na to, kolikšen je bil delež nemštva v trgu. Kot primer je navedel Vojnik, Šoštanj in Ljutomer, kjer je bilo zadostno število nemških otrok zgolj na papirju, medtem ko je bila realnost nekaj povsem drugega. Po Starklovem izvajanju, češ da je bilo v Šoštanju sto nemških učencev, je pokazal na ljudsko štetje leta 1880, ko se je v trgu k Nemcem štelo zgolj 118 ljudi, in pojasnil, da nikakor ni mogoče, da bi v desetih letih število Nemcev naraslo do te mere, da bi bilo med njimi sto šoloobveznih otrok $^{40}$ (po zadnjem štetju se je $k$ Nemcem sicer štela že skoraj polovica šoštanjskega prebivalstva, tj. nekaj več kot 400 ljudi). Seveda je bil Šoštanj pač eden tistih trgov z jezikovno mešanim prebivalstvom, kjer je bila nacionalna struktura pogojena s trenutno politično oblastjo. Potem ko je trško občino ponovno vodila nemška »ekipa «, se je delež Nemcev več kot potrojil, kar je bila posledica slovenskega poraza in nemškega političnogospodarskega pritiska, ko se je marsikdo (povsem zavestno, da ne bi imel kakšnih težav) opredelil za nemštvo, za mnoge ekonomsko odvisne subjekte pa so popisne pole izpolnili kar delodajalci ali pa hišni posestniki, pri katerih so bivali. ${ }^{41} \mathrm{C} e$ bi šlo dejansko za nemške otroke, tako Dečko, ne bi nihče protestiral, tako pa gre za slovensko mladino, ki jo hočejo »stlačiti « v nemške šole in s tem germanizirati, pri čemer so bili še posebej podjetni razni »agenti《 Schulvereina. Podobno je menil tudi za Ljutomer in na koncu obe resoluciji, skupaj z ostalimi slovenskimi poslanci, zavrnil. ${ }^{42}$ Slovensko časopisje je menilo, da $\gg \mathrm{V}$ deželnem zboru gredó razprave še precej mirno naprej, nemški liberalci pa vendar-le ne strpijo tega mirú ter udrihnejo semtertje čez mejo, nad Slovence, posebno posl. dr. Starkel čuti potrebo, da se pokaže za nasprotnika vsemu, kar je slovensko $\ll{ }^{43} \mathrm{Na}$ drugi strani je nemško časopisje nastopalo vse bolj agresivno in ponavljalo, da se na Spodnjem Štajerskem odvija popolna slovenizacija, ter navajalo celjski okrajni zastop, zemljiško knjigo, notarsko zbornico, celjski župnijski urad, slovensko posojilnico v Celju, celjsko slovensko tiskarno, obrtno društvo, odlok o slovenskem reševanju vlog ter izrazilo bojazen pred slovenizacijo okrajnega šolskega sveta in okrajne bolniške blagajne. ${ }^{44}$ Nemštvo na Spodnjem Štajerskem je bilo prestrašeno, $\gg$ marburgerca « pa je dodatno hrabrila nemške vrste, češ da je skrajni čas za strnitev in ostrejši napad. ${ }^{45}$

40 Ibid., 264, 265.

41 Filip Čuček, »Problemi popisovanja občevalnega jezika na Spodnjem Štajerskem (1880-1910),« v: ur. Barbara Šterbenc, Zgodovinski pogledi na zadnje državno ljudsko štetje v Avstrijskem primorju (Ljubljana: Založba ZRC, Zgodovinski inštitut Milka Kosa, 2012), 130-32, 139, 140.

42 Stenographische Protokolle über die Sitzungen des steierm. Landtages. VII. Landtags-Periode. III. Session, 21. Sitzung, 27. 4. 1893, 265, 266.

43 Slovenski gospodar, 4. 5. 1893.

44 Südsteirische Post, 10., 13. 5. 1893.

45 Marburger Zeitung, 25. 5. 1893. 
V tej sesiji se Dečko ni več javil k besedi, zato pa je 30. aprila vložil še interpelacijo zaradi nepravilnega razpisa volitev $\mathrm{v}$ celjsko bolniško blagajno, ki je bila prebrana na predzadnji seji 2. maja $1893^{46}$ (namestnik Kübeck je na zadnji seji sporno izvolitev sistiral). ${ }^{47}$ Zadnjič v tem mandatu pa je govoril februarja 1894 (v četrti sesiji, ki se je začela 19. in 20. decembra 1893, ko je bila zaradi novoletnih praznikov prekinjena, nadaljevala pa se je 9. januarja 1894 in trajala do 17. februarja), ko je avstrijsko vlado že vodil knez Windischgrätz, in ponovno opozarjal na »akcije «nemških poslancev, ki želijo Spodnjo Štajersko prikazati bolj nemško, kot je v resnici bila. Poslancu Starklu, ki je v svojem govoru naglašal, da spodnještajersko nemštvo nima dovolj pravic in da so nemške šole prepotrebne, je skušal pokazati drugačno sliko, in sicer, da večina nemškega prebivalstva živi v Mariboru, Celju in na Ptuju, kjer je nemških šol tako ali tako dovolj, v ostalih (mešanih) trgih pa da je Nemcev premalo, da bi imeli svojo šolo. Ob tem je tudi opozarjal, da spodnještajersko nemštvo vse bolj »navija « za nemške šole, saj je bilo v manjšini, in skuša tudi tako (umetno) večati svojo navzočnost v deželi. ${ }^{48}$

Medtem pa je avstrijsko politično prizorišče (med leti 1893-95) popolnoma zaposlilo celjsko gimnazijsko vprašanje ${ }^{49}$ ki se mu tudi v graškem deželnem zboru niso mogli izogniti. Nasprotno. Celjska gimnazija je v deželnem zboru izzvala vrhunec nacionalnega $\gg v^{2}$ renja $\ll .^{50}$ Že poleti (3. junija) 1894 so v Gradcu zborovali nemški zaupni možje Štajerske, ki so se opredelili proti načrtovani ustanovitvi slovenskih paralelk v Celju. Nato je po burnih debatah v državnem zboru vprašanje paralelk konec leta 1894 sicer nekoliko potihnilo, ponovno pa ga je v peti sesiji štajerskega deželnega zbora (27. in 28. decembra 1894 ter med 8. januarjem in 16. februarjem 1895) oživil graški župan in poslanec Wilhelm Kienzl. Na 18. seji (7. februarja 1895) je predlagal, da naj deželni zbor ustanovitev slovenskih paralelk $v$ celoti zavrne, češ da ne služijo kulturnim potrebam prebivalstva, pač pa zgolj krepitvi slovenstva $\mathrm{v} \gg$ spodnji $\ll$ deželi. ${ }^{51}$ Slovenska delegacija se je po njegovi »akciji« nemudoma odločila zapustiti Gradec, svoje razloge pa je argumentirala v posebni izjavi na seji naslednji dan. ${ }^{52} \mathrm{Kljub}$ temu da so nemški konservativci s kompromisnim predlogom skušali vrniti slovenske poslance $\mathrm{v}$ deželnozborske klopi in da je celo »dr. Kienzl podal nov predlog, naj deželni zbor izvoli poseben odbor, ki naj poskuša rešiti napeto situacijo okoli celjskega vprašanja «, slovenskih poslancev, ki se v tem mandatu niso več vrnili v deželni zbor, niso prepričali. Spodnještajersko nemško časopisje je Kienzlov predlog popolnoma podprlo in 7. februar videlo kot simbol upora ne le spodnještajerskega, pač pa vsega

46 Stenographische Protokolle über die Sitzungen des steierm. Landtages. VII. Landtags-Periode. III. Session, 25. Sitzung, 2. 5. 1893, 336. Domovina, 5. 5. 1893.

47 Stenographische Protokolle über die Sitzungen des steierm. Landtages. VII. Landtags-Periode. III. Session, 26. Sitzung, 3. 5. 1893, 356.

48 Stenographische Protokolle über die Sitzungen des steierm. Landtages. VII. Landtags-Periode. IV. Session, 22. Sitzung, 8. 2. 1894, 218, 219.

49 Janez Cvirn, »Celjsko gimnazijsko vprašanje (1893-1895), « v: Kronika 45, št. 1-2 (1997): 102-11.

50 Marko-Stöckl, Der steiermärkische Landtag, 1698, 1699.

51 Gerhild Troger, »Der steiermärkische Landtag. Sein politisches, kulturelles und soziales Wirken in den Jahren 1890-1900. Phil. Diss.« Graz, 1968, 53-55. Janez Cvirn, Trdnjavski trikotnik. Politična orientacija Nemcev na Spodnjem Štajerskem (1861-1914) (Maribor: Založba obzorja, 1997), 176.

52 Josip Sernec, Spomini (Osrednja knjižnica Celje: Celje, 2003), 77-79. Slovenski gospodar, 14., 21. 2. 1895. 
nemštva monarhije, ki naj bi vse bolj izgubljalo svoje staro posestno stanje. Na drugi strani je slovenski izstop iz deželnega zbora pozdravilo, saj naj bi postajalo slovansko prebivalstvo monarhije že preveč predrzno (npr. na Kranjskem ali na Češkem) in mu je treba končno pristriči peruti. ${ }^{53} \mathrm{Na}$ koncu so resolucijo nemške liberalne večine, ki je slovenska prizadevanja (v prid nacionalnega miru) zavrnila, podprli tudi konservativni poslanci, kar je bilo njihovo sploh prvo protislovensko glasovanje. ${ }^{54}$

Dečko, ki se v peti sesiji tudi v sejah pred Kienzlovim predlogom ni javljal $\mathrm{k}$ besedi, v šesti sesiji (28. in 30. decembra 1895 ter med 8. januarjem in 13. februarjem 1896) deželnozborskih razprav ni spremljal. Čeprav so konservativni državnozborski poslanci julija 1895 skoraj večinsko podprli celjsko postavko (in se nekoliko posuli s pepelom), so slovenski poslanci le nekaj dni pred začetkom šeste sesije sklenili, da jih $\mathrm{v}$ Gradec ne bo. $\mathrm{Z}$ abstinenco, $\mathrm{s}$ katero so poudarili svoje nestrinjanje $\mathrm{z}$ odklonilnim mnenjem graške liberalne večine do ustanovitve celjskih vzporednic, so vztrajali do razpusta deželnega zbora februarja $1896^{55}$ (namesto Dečka, ki je bil vse od začetka druge sesije član peticijskega odseka, je bil v odsek izvoljen poslanec trgovsko-obrtne zbornice Hans Penng von Anheim). ${ }^{56}$

Sredi februarja 1896 je Dečko tako formalno zaključil svoj prvi mandat, v katerem je zastopal »barve « ljutomerske kmečke kurije. V svojih skrbno premišljenih in izpiljenih, večkrat pa tudi energičnih govorih se je (kot večina slovenskih poslancev) bolj ali manj javljal $\mathrm{k}$ besedi takrat, ko je šlo za spodnještajerske zadeve. $\mathrm{V}$ ospredju njegovega zanimanja so bile torej debate, ki so izvirale iz »domačih logov«, zaradi zaostrenih nacionalnih razmer pa so bile večinoma nacionalno $\gg$ obarvane «. Dečko je veljal za predanega narodnjaka, ki je doma in $v$ Gradcu nastopal proti vedno večjim pretenzijam spodnještajerskih Nemcev in za večjo veljavo slovenščine (ter zagotovitev slovenske enakopravnosti) v vseh sferah javnega življenja. Na naslednjih volitvah septembra 1896 je uspešno kandidiral v celjski kmečki kuriji in pozimi istega leta ponovno vstopil v deželni zbor. Tedaj pa so (po zapletih s celjsko gimnazijo) že tako napeta nacionalna nasprotja na Spodnjem Štajerskem dodatno eskalirala, ${ }^{57}$ do novih nacionalnih trenj, ki niso več pojenjala, pa je prišlo tudi v deželnem zboru. Tega so slovenski poslanci odtlej vedno pogosteje zapuščali.

53 Marburger Zeitung, 10., 14. 2. 1895.

54 Cvirn, »Celjsko gimnazijsko vprašanje, « 107, 108. Marko-Stöckl, »Der steiermärkische Landtag, « 1699-1701.

55 Marko-Stöckl, »Der steiermärkische Landtag, « 1700.

56 Stenographische Protokolle über die Sitzungen des steierm. Landtages. VII. Landtags-Periode. VI. Session, Anhang A, Verzeichnis der Mitglieder der steierm. Landtages vom Jahre 1895/96, XXXIV.

57 Več gl. Čuček, Svoji k svojim, 106-11. 


\section{Viri in literatura}

\section{Časopisje}

- Deutsche Wacht, 1890.

- Marburger Zeitung, 1892, 1893, 1895.

- Slovenski gospodar, 1890, 1891, 1893, 1895.

- Südsteirische Post, 1893.

\section{Literatura}

- Baš, Franjo. Prispevki k zgodovini severovzhodne Slovenije. »Doba Ivana Dečka«. Maribor: Založba Obzorja, 1989.

- Cvelfar, Bojan in Andrej Studen. »Posameznosti iz vsakdanjega življenja v Celju pred prvo svetovno vojno. V: Iz zgodovine Celja 1848-1918. Odsevi preteklosti 2. 323-68. Celje: Muzej novejše zgodovine, 1998.

- Cvirn, Janez. »Celjsko gimnazijsko vprašanje (1893-1895).«Kronika 45, št. 1-2 (1997): 102-11.

- Cvirn, Janez. »Josip Sernec, rodoljub z dežele (spremna študija)«. V: Josip Sernec, Spomini, 91-161. Celje: Osrednja knjižnica Celje, 2003.

- Cvirn, Janez. Dunajski državni zbor in Slovenci (1848-1918). Celje: Zgodovinsko društvo; Ljubljana: Znanstvena založba Filozofske fakultete, 2015.

- Cvirn, Janez. Trdnjavski trikotnik. Politična orientacija Nemcev na Spodnjem Štajerskem (18611914). Maribor: Založba obzorja, 1997.

- Čuček, Filip. »Izvršilna oblast na Slovenskem v zadnjih desetletjih dvojne monarhije (s poudarkom na kranjskih akterjih - še posebej pravnikih).« Prispevki za novejšo zgodovino 59, št. 2 (2019): 28-39.

- Čuček, Filip. »Politična dejavnost Ivana Dečka do začetka devetdesetih let 19. stoletja.«Prispevki za novejšo zgodovino 52, št. 1 (2012): 21-38.

- Čuček, Filip. »Problemi popisovanja občevalnega jezika na Spodnjem Štajerskem (1880-1910).« V: Zgodovinski pogledi na zadnje državno ljudsko štetje v Avstrijskem primorju, ur. Barbara Šterbenc, 129-42. Ljubljana: Založba ZRC, Zgodovinski inštitut Milka Kosa, 2012.

- Čuček, Filip. »Slovenski poslanci v Gradcu med prelomom stoletja in razpadom dvojne monarhije.« Časopis za zgodovino in narodopisje 91, št. 1 (2020): 24-41.

- Čuček, Filip. »Slovenski poslanci v štajerskem deželnem zboru 1848-1878.« Časopis za zgodovino in narodopisje 90, št. 2 (2019): 11-25.

- Čuček, Filip. »Spodnještajerski deželnozborski slovenski poslanci za časa Taaffejeve vlade.« Časopis za zgodovino in narodopisje 90, št. 3/4 (2019): 5-19.

- Čuček, Filip. Svoji k svojim. Ljubljana: Inštitut za novejšo zgodovino, 2016.

- Čuček, Filip. Uspehi spodnještajerskih Slovencevv Taaffejevi dobi. Celje: Zgodovinsko društvo, 2007.

- Marko-Stöckl, Edith. »Der steiermärkische Landtag.« V: Die Habsburgermonarchie 1848-1918, Band VII/2, 1683-1718. Wien: Verlag der österreichischen Akademie der Wissenschaften, 2000.

- Sernec, Josip. Spomini. Celje: Osrednja knjižnica Celje, 2003.

- Spindler, Vekoslav. Dr. Ivan Dečko in njegova doba. Maribor: Tisk Mariborske tiskarne d. d., 1938.

- Stimmer, Gernot. Eliten in Österreich 1848-1970. Wien, Köln, Graz: Böhlau Verlag, 1997.

- Troger, Gerhild. »Der steiermärkische Landtag. Sein politisches, kulturelles und soziales Wirken in den Jahren 1890-1900. Phil. Diss.« Graz, 1968. 


\title{
Tiskani viri
}

- Stenographische Protokolle über die Sitzungen des steierm. Landtages. VII. Landtags-Periode:

- I. Session, 11., 16., 19., 21. Sitzung, 1890.

- II. Session, 21., 23. Sitzung, 1892; Sachregister.

- III. Session, 20., 21., 25., 26. Sitzung, 1893; Sachregister.

- IV. Session, 22. Sitzung, 1894; Sachregister.

- VI. Session, Anhang A, Verzeichnis der Mitglieder der steierm. Landtages vom Jahre 1895/96, XXXIV.; Sachregister.

\section{Filip Čuček}

\section{IVAN DEČKO'S FIRST TERM OF OFFICE IN THE PROVINCIAL ASSEMBLY (1890-96)}

\begin{abstract}
SUMMARY
\end{abstract}
In 1885, Ivan Dečko moved from Maribor to Celje, where he visibly encouraged the Slovenian "breakthrough" in the city by the river Savinja. By the beginning of the 1890s, when he entered the Provincial Assembly, he had developed into a completely mature political personality. In Graz, he promptly demonstrated his political zeal by submitting an interpellation that called upon the deputy - in the Slovenian language - to eliminate the irregularities in certain Lower Styrian district boards, which would reply to Slovenian applications in the German language. He and Josip Sernec were thorns in the side of Lower Styrian Germans, especially in Celje. Their agility resulted in the extremely tense national relations in Celje (the events during the establishment of the Celje Sokol gymnastic society) and gave rise to the solidarity among Germans and consequently Slovenians as well.

The German newspapers kept claiming that total "Slovenisation" was underway in Lower Styria, referring to the Celje district representation, land register, Chamber of Notaries, Celje parochial office, the Slovenian printing house and Slovenian loan bank in Celje, crafts association, and the decree about processing applications in the Slovenian language. They also expressed their fear of the impending Slovenisation of the district school board and district sickness fund. Therefore, Dečko persisted in his efforts passionately, especially regarding the linguistic disputes in Lower Styria, which he also presented in the Provincial Assembly. The Lower Styrian Germans were concerned, while the German press additionally encouraged the German ranks, claiming that it was high time that their ranks were consolidated and a more resolute attack organised. Also under Dečko's influence, the clever Slovenian politics at the beginning of the 1890s won over the rural areas completely while restricting the Lower Styrian Germans to the cities and certain towns. 